\title{
Protection of intellectual property rights in the European Union: The role of customs authorities on the example of Poland
}

\author{
Małgorzata Czermińska
}

\begin{tabular}{|c|c|}
\hline & \\
\hline \multicolumn{2}{|c|}{$\begin{array}{l}\text { Objective: The aim of the article is to measure and analyze the scale of trade in coun- } \\
\text { terfeit and pirated goods in the European Union in order to provide decision-makers } \\
\text { with solid empirical evidence about this threat. The specific objective is to show the } \\
\text { role of customs authorities in preventing infringements of intellectual property rights. }\end{array}$} \\
\hline \multicolumn{2}{|c|}{$\begin{array}{l}\text { Research Design \& Methods: The research methods include the critical review of ex- } \\
\text { isting literature, analysis of relevant legal and official documents of the European Union } \\
\text { and the case study of the role of the Polish customs authorities in preventing infringe- } \\
\text { ments of intellectual property rights. }\end{array}$} \\
\hline \multicolumn{2}{|c|}{$\begin{array}{l}\text { Findings: The infringement of IPR is no longer limited to branded products such as } \\
\text { clothes, luxurious watches, brand-name sunglasses, handbags, but it also concerns } \\
\text { more and more popular foodstuffs, pharmaceuticals, chemicals, electronic items } \\
\text { and household appliances. }\end{array}$} \\
\hline \multicolumn{2}{|c|}{$\begin{array}{l}\text { Contribution \& Value Added: This paper provides a description of copyright protec- } \\
\text { tion, counterfeiting and piracy, but also contains a reference to legal regulations appli- } \\
\text { cable within the European Union and relating to this area, changes to such regulations, } \\
\text { as well as the scope of activity, working procedures (and their consequences) of EU } \\
\text { Member States' customs authorities, with special attention given to Polish customs. }\end{array}$} \\
\hline \multicolumn{2}{|r|}{ research paper } \\
\hline Keywords: & \\
\hline JEL codes: & \\
\hline & \\
\hline
\end{tabular}

\section{Suggested citation:}

Czermińska, M. (2020). Protection of intellectual property rights in the European Union: The role of customs authorities on the example of Poland. International Entrepreneurship Review (previously published as International Entrepreneurship / Przedsiębiorczość Międzynarodowa), 6(2), 37-54. https://doi.org/10.15678/IER.2020.0602.03 


\section{INTRODUCTION}

Intellectual property (IP) is a powerful tool designated to stimulate innovations, growth, competitiveness and create new jobs. When properly protected and effectively used, intellectual property rights give great competitive advantage on the market. Trade in counterfeit and pirated goods that infringe intellectual property rights is the major challenge in a global innovation-based economy. These practices produce adverse effects on the sales and profits of interested companies and also create a detrimental impact on governments, companies and consumers as regards their revenues, economy, health and safety. Organised criminal gangs are perceived as groups that play a more and more influential role in such activities, as they gain substantial benefits from counterfeiting and piracy.

Increased technological advancement and digital revolution pose new challenges in the IP environment, on the one hand, but they also offer new opportunities, on the other. When properly protected and effectively used, intellectual property rights give clear competitive advantage on the market. Despite the great significance of intellectual property, its contribution to innovations and social development, innovative companies, particularly small and medium-sized enterprises (SMEs) and start-ups, still face serious problems concerning the protection of their inventions and creative works. Furthermore, the enforcement of intellectual property rights - which often entails combating piracy and counterfeiting - has proved to be more difficult in a digital world and amid globalisation, specifically beyond state borders.

According to a study carried out by EU Intellectual Property Office (EUIPO) and the OECD in 2019, estimates of IPR infringement in international trade in 2016 could reach as much as $3.3 \%$ of world trade. Counterfeit and pirated goods could make up as much as 6.8 $\%$ of EU imports, amounting to EUR 121 billion (EUIPO, EUROPOL, 2019). In recent years, this amount has significantly increased (EU publications, 2019).

The paper assumes that customs authorities play a significant role in limiting the influx of goods that infringe intellectual property rights. Moreover, goods that infringe intellectual property rights are no longer luxury goods, but everyday goods.

The aim of the article is to measure and analyze the scale of trade in counterfeit and pirated goods in the European Union in order to provide decision-makers with solid empirical evidence about this threat. The specific objective is to show the role of customs authorities in preventing infringements of intellectual property rights. The research methods include the critical review of existing literature, analysis of relevant legal and official documents of the European Union and the case study of the role of the Polish customs authorities in preventing infringements of intellectual property rights.

\section{LITERATURE REVIEW}

Intellectual property right infringements in the form of counterfeiting and piracy have yet to establish itself as an independent stream of research. The subject has been studied from numerous perspectives, including management, logistics and law. Literature on counterfeiting and piracy, which is relatively vast, includes, in principle, several main, separate aspects of this phenomenon. The first research area encompasses the general characteristics of counterfeiting and piracy perceived as a growing, global problem which causes 
serious concerns among consumers, governmental units, law enforcement agencies and companies. This crime involves a variety of illegal activities associated with the infringement of intellectual property rights, and affecting nowadays all types of goods (Bush at al., 1989; Chaudhry et al., 2017; Heinonen at al., 2014). Despite the diversity of counterfeit goods, which is reflected through their complexity, manufacturing technology, investment in manufacturing equipment, potential threats or values for users and a scale of conflict between counterfeit producers and local authorities, they (counterfeiters) are often treated in the scientific literature as a homogeneous group. Hence the results of empirical research by means of a cluster analysis performed by Staake at al. (2012) deserve particular attention. The said results point to five different groups of counterfeiters which brand owners have to deal with: (1) disaggregators, (2) imitators, (3) fraudsters, (4) desperados, and (5) smugglers (Staake at al., 2012). The results of this research are conducive to a more diversified understanding of the learning strategy and the development of each group and help companies achieve a better position on the counterfeit market and devise a strategy for combating counterfeit articles.

The second research area relates to international and national legal frameworks and institutions set up with a view to managing and combating goods that infringe international property rights (Alfadhel, 2015; Jain, 1996; Jandhyala, 2015; Khan \& Sokoloff, 2001; Mercurio, 2012; Rinnert, 2015; Vrins, 2018). Interesting research into determinants of IPR protection was conducted by Marron and Steel (2000). Based on data pertaining to computer piracy, they examined differences in the protection of intellectual property across individual countries. The results of the research show that intellectual property is protected to a greater extent in developed economies, and lower piracy rates are reported in high-income countries. Interestingly enough, the authors further claim that such protection is also conditional on cultural factors. Countries with an individualistic culture have lower piracy rates than countries with a collectivist culture. Piracy rates are also lower in countries where powerful institutions have been created with a view to enforcing agreements and protecting intellectual property. The results in question indicate that national intellectual property policies reflect not only economic problems but also the culture and national institutions (Marron \& Steel, 2000).

The third research area comprises an analysis of consumer behaviours regarding indicators of attitudes, intentions and actual purchasing behaviours, including also purchases of counterfeit and pirated goods. This area has received considerable attention in the literature, however, several publications are particularly worth mentioning (Albers-Müller, 1999, Casola, at al., 2009). Consequently, marketing researchers have drawn a distinction between deceptive and non-deceptive counterfeiting (Bloch at al., 1993; Grossman \& Shapiro, 1988a; Grossman \& Shapiro 1988b; James \& Lemon, 2013; Nill \& Shultz, 1996). Counterfeiting is deceptive when consumers are tricked and believe that the product they are buying is genuine. On the other hand, non-deceptive counterfeiting occurs when circumstances surrounding the purchase - specifically, the location, price difference and quality level - prove beyond any doubts that the goods are fake. Consumers who intentionally buy counterfeit goods, desire to have their visual attributes - a well-known brand or logo - however, by paying less than in the case of good-quality genuine articles (Cordell at al., 1996; Gentry at al., 2001; Gentry at al., 2006; Grossman \& Shapiro, 1988b; Phau \& Teah, 2009; Turkyilmaz \& Uslu, 2014; Vida, 2007; Wee, at al., 1995). 
The fourth research area deals with the consequences of counterfeiting and piracy - not only negative, but sometimes also positive ones - which are faced by companies whose operations are legitimate and by economies (Chaudhry \& Walsh, 1996; Chaudhry \& Zimmerman, 2009; OECD, 2008). Another one, the fifth research direction relating to a literature study includes managerial strategies, instruments used and actions taken by companies in response to counterfeiting and piracy (Berman, 2008; Cesareo \& Stötinger, 2015; Chaudhry at al., 2005; Chaudhry at al., 2009; Li, 2004; Liang \& Xue, 2010; Yang at al., 2008). And finally, the sixth research area reflects a view on the supply of illicit products, by examining the supply chains and distribution of entities committing the breach (Cho at al., 2015; Piquero, 2005; Speier at al., 2011; Wilson \& Kinghorn, 2015; J. Zhang \& R. Q. Zhang 2015).

This paper covers several research areas, which means that it not only provides a description of copyright protection, counterfeiting and piracy, but also contains a reference to legal regulations applicable within the European Union and relating to this area, changes to such regulations, as well as the scope of activity, working procedures (and their consequences) of EU Member States' customs authorities, with special attention given to Polish customs. The juxtaposition of several research areas, an analysis - both theoretical and empirical, gives definitely strong grounds for the claim that this work is unique.

\section{MATERIAL AND METHODS}

The proliferation of counterfeiting operations is common in most countries all over the world. An increase in the number of counterfeit goods is not only seen in the territories where such goods are manufactured, since they are also frequently exported to other countries. Consequently, further movement of counterfeit goods through borders has become one of the biggest challenges for law enforcement agencies, and particularly for customs authorities. This research used data from the European Commission and the EUIPO, as well as statistics from Polish customs authorities, which refer mainly to seizures made by customs authorities, in order to identify trends in the growth of counterfeiting. The research includes also an evaluation of a risk associated with counterfeiting and piracy in the main product sectors.

\section{RESULTS AND DISCUSSION}

\section{EU Regulations on Intellectual Property Right Protection: Main Provisions and Course of Changes}

The aim of EU legislation on border measures for IPR protection is to guarantee consumers safety and protection, respect for holders' IPR and the financial interests of the EU in an economic area that is both competitive and open to free competition. It should serve to promote business innovation and competitiveness and safeguard jobs while protecting national economies. However, its main objective is to provide the single market and consumers with more effective protection in a bigger Community (European Commission, 2003).

The first EU provisions concerning procedures for the protection of intellectual property rights and the prevention of infringement were laid down in the Regulation No 3842/86 of 1986 (Council Regulation (EEC) No 3842/86), and subsequently - the Regulation No 3295/94 of 1994 (Council Regulation (EC) No 3295/94) amended by Council Regulation (EC) No 
241/99 of 1999 (Council Regulation (EC) No 241/99) (for details, see Acquah, 2015). The EU Council adopted new regulations on combating counterfeiting and piracy, simplifying measures and conditions governing activities undertaken by customs authorities with respect to goods suspected of infringing intellectual property rights, which entered into force on 1 July 2004 (Council Regulation (EC) No 1383/2003; Commission Regulation (EC) No 1891/2004; amended by Commission Regulation (EC) No 1172/2007).

After ten years of combating the counterfeiting of goods in the European Union under the 2003 Regulation, a new Regulation No 608/2013 was enacted, which entered into force on 1 January 2014 (Regulation (EU) No 608/2013). The said Regulation was supplemented by the Commission Implementing Regulation (EU) No 1352/2013 of 4 December 2013 concerning application for action (AFA) forms filed by copyright holders. The new Regulation should strengthen the enforcement of intellectual property rights by customs authorities and improve the effectiveness of law amidst economic, commercial and legal changes. The new regime aims to:

- Implement a mandatory procedure for destruction of goods violating law without the need for a court order.

- Prevent the growing influx of counterfeit goods shipped by post and couriers, stemming from an increase in Internet sales; and

- Expand the scope of intellectual property rights on which right holders may rely with respect to customs law enforcement procedures.

Major innovations introduced by the EU regulation No 608:

- Customs protection extended to new rights and infringements.

- New specific procedure for small consignments.

- Exchange of information with third countries for goods in transit suspected of infringing an intellectual property right.

- Establishment of a central electronic database (COPIS) where all information relating to applications requesting the customs authorities to take action for the enforcement of IPR is stored. COPIS is the new central database of the European Union in which the Member States enter all the information needed to fill in the application for action (AFA) that they intend to submit to the competent customs services.

The Regulation (EU) No 608/2013 set out conditions and procedures relating to actions taken by customs authorities with respect to goods suspected of infringing intellectual property rights, which are or should be under their supervision or control. As part of their procedural rights, customs authorities can only find that goods are "goods suspected of infringing intellectual property rights". The Regulation (EU) No 608/2013 does not lay down any criteria for stating whether there has been an infringement of intellectual property right or not. The matter of whether an intellectual property right has been infringed or not is resolved by substantive law on intellectual property in accordance with the interpretation of competent national courts and the Court of Justice of the European Union (Commission notice, 2016).

In order to strengthen the enforcement of intellectual property rights, the scope of customs authorities' activities was extended to include the types of rights and infringements which were not covered by the Regulation (EC) No 1381/2003. Under new regulations detention is permitted also where the customs authority have suspicions that a utility 
model, trade name or topographies of semiconductor products have been infringed. In this case, a good example includes mobile phones and their accessories. Goods classified under this category were detained mainly on account of trade mark infringement, and on rare occasions - where a patent or an industrial design was infringed.

To deal with an increased number of counterfeit and pirated goods contained in small consignments that are usually delivered to the EU by post or shipped by courier companies after being purchased online and to reduce administration costs and expenses arising from the handling of the above cases, a new simplified procedure for small consignments (containing up to three units or having a gross weight of not more than two kilograms) of counterfeit and pirated goods was introduced. Such goods can be destroyed without the applicant's express consent, provided, however, that the application for actions to be taken by customs does not rule out this procedure.

In the event of suspected counterfeiting, the Regulation provides for (in addition to the destruction of small consignments) two types of actions to be taken by customs:

- Ex officio actions (accounting for approx. two per cent of actions taken by customs within the entire EU (European Commission, 2019, p. 8.) (it does not apply to perishable goods); and

- Actions on application (national or Union application) previously filed in respect of intellectual property rights registered within the entire EU. The number of applications for protection filed by copyright holders is increasing, for comparison: in 2007 $-10,260$, in 2018 , it was three times bigger - 34,047. Customs authorities can perform actions either on the basis of applications for action (AFA) filed by right holders or on their own initiative (ex officio). National AFAs are filed in a Member State - they concern actions to be carried out by customs authorities within that specific Member State. Intellectual property right holders can file a Union AFA, which is effective in more than one Member State. Such an application must be filed with the central customs authority of the relevant Member State, and subsequently, it can be immediately provided to other designated Member States.

The previous regulations permitted the use of a so-called simplified procedure, in specific cases for all goods, irrespective of the type of transport and quantity of goods - nevertheless, it was not mandatory. Whether this course of dealing was followed or not depended on who enjoyed intellectual property rights, and on the importer. If a settlement regarding the destruction of goods was reached between the said parties involved in the procedure, it happened very quickly and it was not necessary to bring a legal action. Polish customs officers used this procedure very rarely. The simplified procedure for destruction of goods - which was optional under the former regulation - has become a standard mandatory procedure in all Member States. It allows for the quick destruction of goods suspected of infringing intellectual property rights without the need for seeking a court order, that is to say, it is not necessary to determine whether an intellectual property right has been infringed or not; after the decision holder has confirmed in writing that - in their opinion - an IPR has been infringed and with the consent of both parties.

Under the "standard procedure", following a written confirmation of the decision holder that - in their opinion - an intellectual property right has been infringed, and with explicit or implicit consent given by both parties (i.e. the right holder and the holder of goods/the declarant), suspected goods can be destroyed. Otherwise goods are released, 
unless the decision holder notifies customs authorities that he or she has instituted proceedings to determine whether an intellectual property right has been infringed or not. The time limit for expressing consent to the destruction of goods or notifying customs authorities that proceedings have been instituted is ten working days (three days for perishable goods) and, where appropriate, in the event that the proceedings have been initiated, it may be extended by additional ten working days at most (Fig. 1).

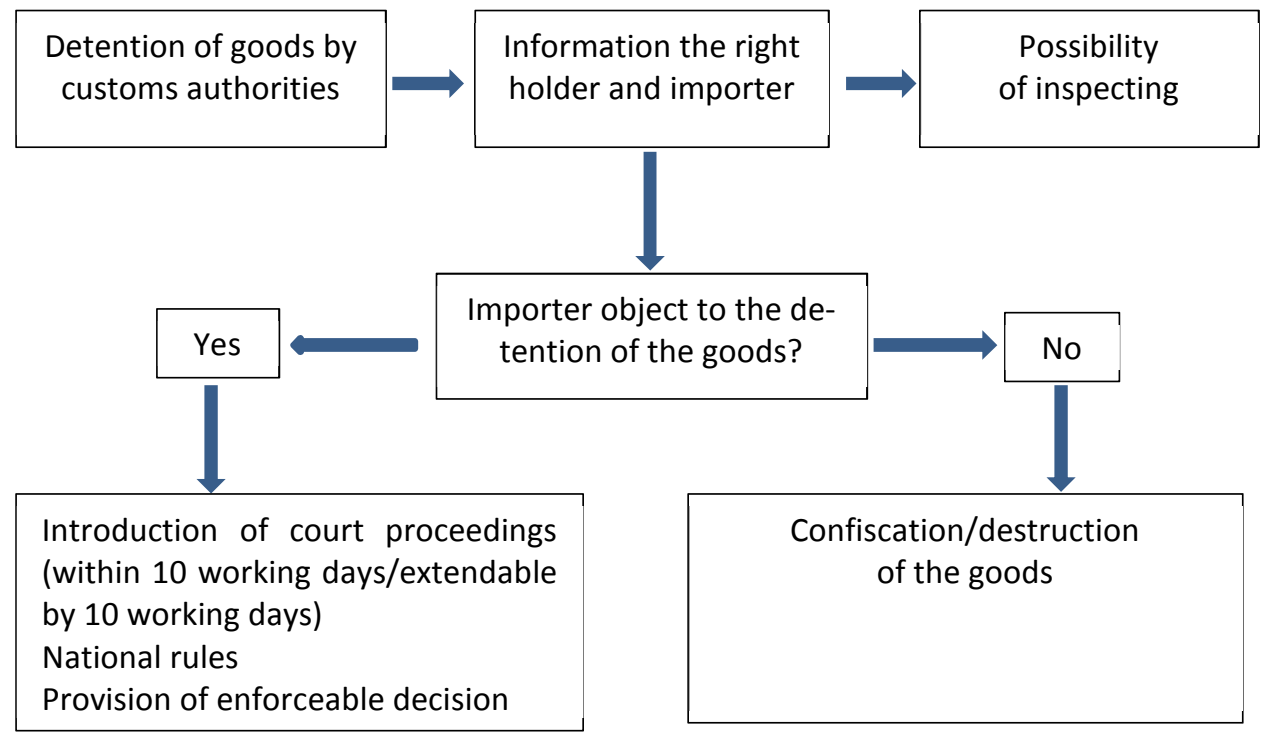

Figure 1. Detention procedure in the European Union

Source: own elaboration based on Regulation (EU) No 608/2013.

Both the standard procedure and the small consignment procedure allow the possibility of the destruction of goods on the basis of implied consent of the holder of goods/the declarant instead of their express consent. The holder of goods is usually the addressee, and the declarant lodging a declaration for customs clearance purposes is e.g. the sender or, in certain cases, a courier company (in principle, customs officers contact the owner of goods, but if his or her particulars are unknown - they contact the declarant).

\section{Extent of Intellectual Property Right Infringements: Detentions by EU Customs Authorities}

As already mentioned, challenges associated with combating counterfeit goods require customs authorities to react properly and in a more stringent manner. In this context, the traditional role of customs authorities has been increased, and it now includes, but is not limited to, facilitating legitimate trade and enforcing intellectual property at borders.

There are arguments for the claim that ensuring protection on borders is of paramount importance to preventing counterfeit goods from entering target markets or leaving them. Such actions are considered more effective than the detention of goods after they have been admitted to trading on such markets. Therefore, border measures are deemed to be 
more effective, especially when they entail using preventive measures which are less expensive than court proceedings (Widdowson, 2007).

The majority (approx. 90,000) of detentions of goods suspected of intellectual property right infringement at EU's customs borders was observed between 2011 and 2012, whereas recent years have seen a sharp decrease in the number of such detentions. In 2018, Customs authorities made over 69,000 detentions (Tab. 1), the number of seized counterfeit goods brought to the EU rose in 2018 due to a large quantity of small consignments delivered by postal and courier services. 2018 saw considerably fewer detentions of goods - almost 26.7 million, compared to previous years - over 114.7 million articles infringing intellectual property in 2011, and 103 million in 2010 (Tab. 1). The number of seized consignments went up from 57,433 in 2017 to 69,354 in 2018, even though the total quantity of articles detained is lower than in recent years.

Table 1. Cases Involving Intellectual Property Right Infringements in Cross-border Trade in Goods within EU between 2003 and 2018

\begin{tabular}{|c|c|c|c|c|c|c|c|c|c|c|c|c|c|c|c|c|}
\hline 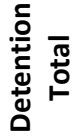 & ஜ̊̊ & ঠ্ঠ & ํㅗㅇ & ஜ̊ & 유 & $\stackrel{\infty}{\infty}$ & ஜํ․ & 웅 & 공 & 공 & $\stackrel{m}{\stackrel{n}{\nu}}$ & 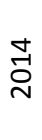 & 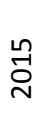 & $\begin{array}{l}\mathscr{7} \\
\stackrel{\sim}{0}\end{array}$ & 귱 & $\stackrel{\infty}{\stackrel{\infty}{\sim}}$ \\
\hline 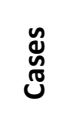 & $\begin{array}{l}\stackrel{\circ}{0} \\
\text { No } \\
\text { Oे }\end{array}$ & $\begin{array}{l}\overrightarrow{-} \\
\stackrel{m}{n} \\
\stackrel{N}{N}\end{array}$ & $\begin{array}{l}\stackrel{+}{N} \\
\stackrel{0}{0}\end{array}$ & $\begin{array}{l}\underset{m}{m} \\
\stackrel{m}{m}\end{array}$ & $\begin{array}{l}-1 \\
\hat{\sigma} \\
\text { r্ }\end{array}$ & $\begin{array}{l}\text { - } \\
\text { ñ } \\
\text { gे }\end{array}$ & 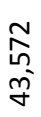 & 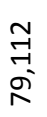 & $\frac{\text { nf }}{\stackrel{\sim}{\sigma}}$ & $\begin{array}{l}\stackrel{m}{f} \\
\stackrel{-}{\circ}\end{array}$ & 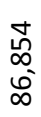 & $\begin{array}{l}\text { ने } \\
\text { ஸे }\end{array}$ & $\begin{array}{l}\infty \\
\text { Oे } \\
\stackrel{-}{\infty}\end{array}$ & $\begin{array}{l}\infty \\
\infty \\
\stackrel{-}{-1} \\
\tilde{n}\end{array}$ & $\begin{array}{l}\stackrel{m}{m} \\
\stackrel{N}{n}\end{array}$ & $\begin{array}{l}\text { फे } \\
\text { m. } \\
\text { बె }\end{array}$ \\
\hline 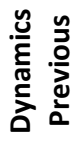 & ঃ & $\stackrel{\infty}{\circ}$ & 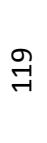 & $\underset{\sim}{\stackrel{P}{-}}$ & $\stackrel{ન}{\rightrightarrows}$ & $\stackrel{m}{\rightarrow}$ & $\infty$ & $\underset{\sim}{-1}$ & 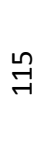 & னু & ஜூ & $\underset{\sim}{\stackrel{-}{-}}$ & $\stackrel{\infty}{\infty}$ & $\stackrel{\infty}{\sim}$ & б' & $\underset{\sim}{\stackrel{\sim}{\sim}}$ \\
\hline 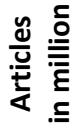 & مָ & 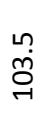 & 官 & \begin{tabular}{l}
0 \\
$\infty$ \\
\multirow{-}{*}{}
\end{tabular} & 뭄 & 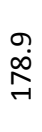 & 국 & $\begin{array}{c}m \\
\stackrel{m}{\rho} \\
\stackrel{\sim}{r}\end{array}$ & $\begin{array}{l}\stackrel{-}{\dot{J}} \\
\underset{\sim}{-}\end{array}$ & बे & ஸ़ & $\stackrel{\varphi}{\stackrel{\varphi}{m}}$ & $\hat{o}$ & $\underset{\sim}{\stackrel{\sim}{\sigma}}$ & $\stackrel{+}{\stackrel{+}{m}}$ & $\vec{v}$ \\
\hline 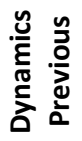 & 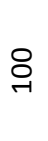 & $\underset{7}{\stackrel{7}{7}}$ & $\stackrel{n}{\wedge}$ & $\underset{\sim}{\stackrel{?}{-}}$ & 부 & $\stackrel{N}{N}$ & $\mathscr{0}$ & $\infty$ & $\underset{\nearrow}{-}$ & $\stackrel{\leftrightarrow n}{n}$ & পి & ब઼ & $\underset{\sim}{\stackrel{\sim}{二}}$ & 국 & $\stackrel{6}{N}$ & $\infty$ \\
\hline
\end{tabular}

Source: own calculation based on European Commission (2008, 2013, 2017, 2018, 2019).

Due to the fact that the number of detained goods fell, their retail value, set as a price at which goods would have been sold in retail trade on Member States' market, also declined: in 2018 it amounted nearly to EUR 738 million, in 2017 - EUR 582 million, whereas in 2011 - as much as EUR 1.1 billion (Tab. 2). For the assessment of the value of detained goods, the domestic retail value (DRV) is taken into consideration, which is a price at which goods 
would have been sold in retail trade on the Member States' market, had they been genuine. Goods infringing intellectual property rights are more and more frequently sold at a price that is similar to the price of genuine goods and they easily drive the latter out from the market - except for luxurious goods. It is often difficult to differentiate counterfeit goods from genuine ones, as the former are confusingly similar to the latter. Undoubtedly, this is one of the reasons why the number of detained goods has diminished that much.

Table 2. Trends in Seizures in the European Union between 2010 and 2018

\begin{tabular}{|c|c|c|c|c|c|c|c|c|c|}
\hline Criteria & 2010 & 2011 & 2012 & 2013 & 2014 & 2015 & 2016 & 2017 & 2018 \\
\hline $\begin{array}{l}\text { Numbers } \\
\text { of seizures/cases }\end{array}$ & $\begin{array}{l}\text { ज } \\
\text { ने } \\
\text { शे }\end{array}$ & $\begin{array}{l}\stackrel{n}{+} \\
\text { aे }\end{array}$ & \begin{tabular}{l}
$m$ \\
\multirow{2}{f}{} \\
$\stackrel{-}{\circ}$
\end{tabular} & $\begin{array}{l}\text { 芯 } \\
\infty \\
\emptyset^{-}\end{array}$ & $\begin{array}{l}\text { ने } \\
\text { ผे }\end{array}$ & $\begin{array}{l}\infty \\
\text { O } \\
-i \\
\infty\end{array}$ & \begin{tabular}{l}
\multirow{1}{\infty}{} \\
$\stackrel{-1}{n}$ \\
$\tilde{n}$
\end{tabular} & 孞 & 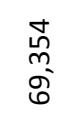 \\
\hline $\begin{array}{l}\text { Numbers } \\
\text { of articles/articles }\end{array}$ & 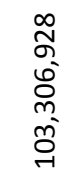 & 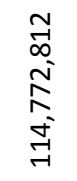 & $\begin{array}{l}\text { 号 } \\
\text { సે } \\
\text { ने } \\
\text { જे }\end{array}$ & 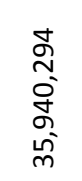 & 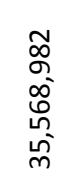 & 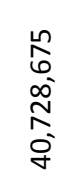 & 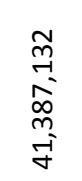 & $\begin{array}{l}m \\
\stackrel{m}{0} \\
\stackrel{-}{0} \\
\stackrel{+}{+} \\
\stackrel{-}{m}\end{array}$ & 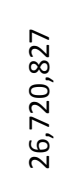 \\
\hline Estimated value (EUR)* & 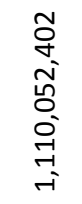 & 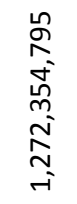 & 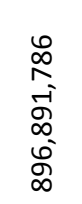 & 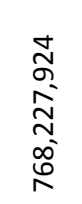 & 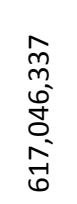 & 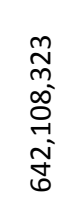 & 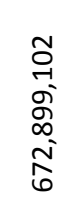 & 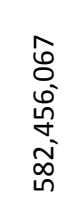 & $\begin{array}{l}\hat{Q} \\
\infty \\
\stackrel{\sim}{\sim} \\
\underset{\sim}{-} \\
\stackrel{\infty}{N}\end{array}$ \\
\hline Articles per seizure & $\begin{array}{l}\mathscr{p} \\
\text { mi } \\
\text {-i }\end{array}$ & $\stackrel{\substack{n\\
}}{-1}$ & F & $\underset{\forall}{\stackrel{\nabla}{*}}$ & $\underset{m}{\stackrel{N}{m}}$ & ํํ & นึ & 守 & 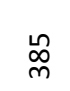 \\
\hline Value per seizure (EUR) & \begin{tabular}{l}
$\vec{n}$ \\
0 \\
\multirow{+}{*}{}
\end{tabular} & $\begin{array}{l}\text { \&े } \\
\text { mे } \\
\rightarrow\end{array}$ & $\begin{array}{l}\text { ने } \\
\text { बे }\end{array}$ & $\begin{array}{l}\mathfrak{L}_{+}^{+} \\
\infty \\
\infty\end{array}$ & 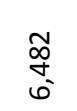 & $\begin{array}{l}\infty \\
\stackrel{+}{N} \\
\text { N }\end{array}$ & 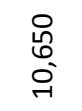 & $\begin{array}{l}\text { 孚 } \\
\underset{0}{-1} \\
\text { - }\end{array}$ & $\begin{array}{l}\hat{\AA} \\
0 \\
0 \\
0\end{array}$ \\
\hline
\end{tabular}

* Domestic retail value

Source: own calculation based on European Commission (2013, 2018, 2019).

Second In more than $89 \%$ of cases, interventions made by customs concerned imports, approx. $7 \%$ of goods were under the transit procedure with the destination in the EU and approx. $1 \%$ of cases concerned re-exports with the destination outside the European Union (European Commission, 2019, p. 13). Taking into consideration the number of detained articles, it is clear that the share of articles detained in transit is greater (15.5\%), which stems from the fact that most goods were detained during sea or air transport (in which case consignments were large), whereas as regards imports, the majority of goods were detained during postal deliveries, with the quantity of articles being obviously smaller.

The counterfeiting issue concerns almost all products. When it comes to goods detained by customs officers, the majority of them included (2017): foodstuffs (24\%), toys (11\%), cigarettes (9\%), "other goods" (9\%) and clothing (7\%); in total, they accounted for $60 \%$ of all detained goods (Fig. 2 and own calculation based on European Commission 2019, Annex 2). The most important categories of detained articles in 2018 were: cigarettes, which repre- 
sented $15.6 \%$ of the total number of detained articles, followed by toys (14.2\%), packaging materials (9.4\%), labels, tags and stickers $(8.9 \%)$ and clothing $(8.6 \%)$. It must be noted that the number of detained everyday goods which are potentially dangerous to consumers' health and safety is on the rise (and to be precise, this concerns the suspected infringement of trade marks): food and beverages, body care articles, medicines, electrical household goods and toys; in total accounted for $43.3 \%$ (2017 r.) of all articles detained (which means a considerable rise compared to 2015 and $2016-25.8 \%$ and $34.2 \%$ respectively).

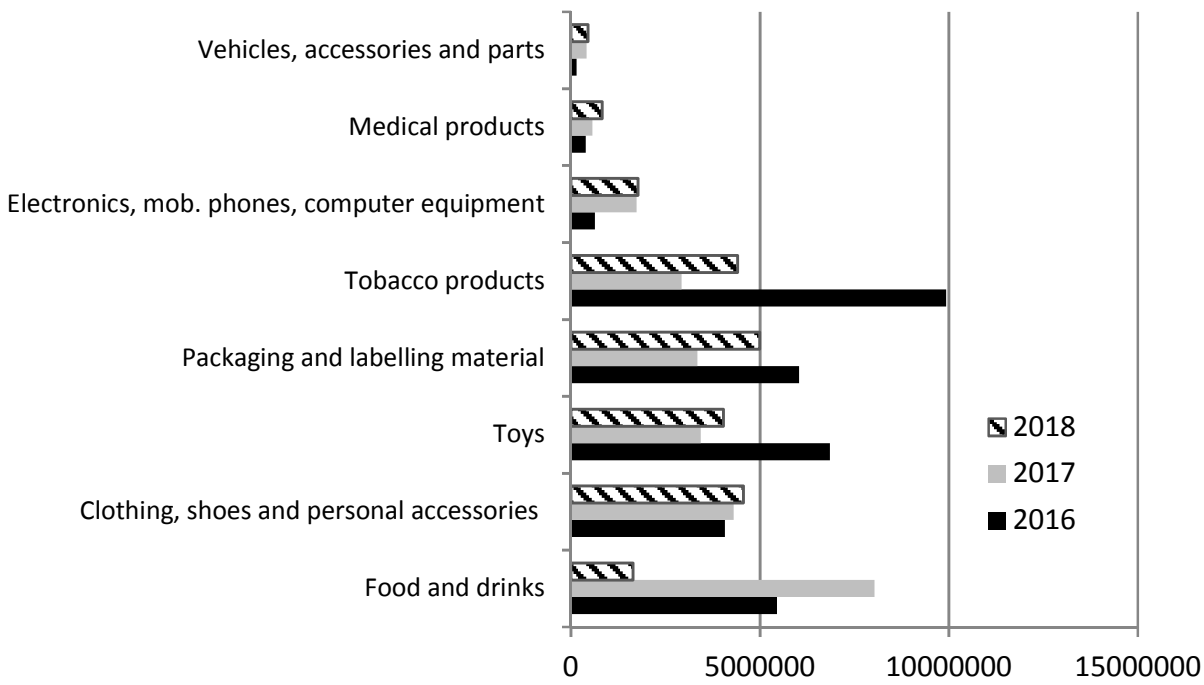

Figure 2. Number of IP infringing articles seized per product category, in the EU for 2016-2018 Source: own calculation based on European Commission $(2018,2019)$.

Table 3. Cases and Articles Detained at Borders in Relation to Infringement of EU Intellectual Property Rights - Structure Broken Down by Branches of Transport between 2006-2017, in per cent

\begin{tabular}{|c|c|c|c|c|c|c|c|c|c|c|c|c|}
\hline Criteria & ஜ̊ํㅁ & ઠ્ષิ & \&્స & 옹 & 옴 & ন্ণ & 곡 & $\stackrel{m}{\stackrel{m}{N}}$ & 突 & กั & $\begin{array}{l}0 \\
\stackrel{N}{2}\end{array}$ & નิํํ \\
\hline \multicolumn{13}{|c|}{ Cases/ means of transport } \\
\hline Air and express courier & 53.1 & 52.9 & 43.2 & 43.6 & 26.1 & 28.2 & 27.3 & 26.0 & 18.1 & 25.4 & 30.7 & 30.8 \\
\hline Post & 23.0 & 20.0 & 24.4 & 34.4 & 61.9 & 62.9 & 61.8 & 64.0 & 77.0 & 70.5 & 65.3 & 64.8 \\
\hline Rail & 0.5 & 0.3 & 0.2 & 0.1 & 0.1 & 0.2 & 0.00 & 0.03 & 0.01 & 0.00 & 0.02 & 0.02 \\
\hline Road & 11.8 & 16.6 & 21.3 & 13.1 & 7.2 & 4.9 & 6.8 & 5.7 & 1.9 & 1.3 & 1.1 & 1.5 \\
\hline Sea & 7.6 & 7.9 & 9.4 & 8.7 & 4.5 & 3.8 & 4.1 & 4.4 & 2.9 & 3.0 & 2.9 & 2.9 \\
\hline \multicolumn{13}{|c|}{ Articles / means of transport } \\
\hline Air and express courier & 6.9 & 10.8 & 6.5 & 17.1 & 9.4 & 7.9 & 19.4 & 22.2 & 17.1 & 17.3 & 16.4 & 22.9 \\
\hline Post & 0.4 & 1.0 & 0.4 & 0.9 & 1.0 & 1.6 & 2.7 & 3.1 & 2.3 & 2.2 & 2.2 & 2.7 \\
\hline Rail & 0.2 & 0.2 & 0.05 & 0.4 & 0.2 & 0.1 & 0.0 & 0.2 & 0.9 & 0.0 & 0.04 & 0.12 \\
\hline Road & 15.3 & 28.3 & 11.8 & 6.3 & 7.7 & 22.3 & 19.2 & 11.9 & 9.8 & 6.5 & 14.3 & 9.9 \\
\hline Sea & 75.5 & 58.1 & 80.9 & 75.1 & 81.6 & 67.9 & 58.6 & 62.6 & 70.0 & 74.0 & 67.0 & 64.4 \\
\hline
\end{tabular}

Source: own calculation based on Report on EU Customs enforcement of Intellectual Property Rights (2019). 
In recent years, most detentions of goods at borders have been seen in relation to consignments delivered by post, courier and by air (in 2017, it was in total over $90 \%$ ) (Tab. 3). This results mainly from the growing popularity of online shopping. And as regards the number of goods detained, sea transport occupies a dominant position, which stems from the fact that in this particular case, consignments are shipped in containers, that is to say - in large bulks; the share of air transport and courier deliveries, as well as road transport has also risen dramatically over the last two years (Tab. 3 ).

\section{Customs Authorities' Activity in Poland Associated With Combating Goods Infringing Intellectual Property Rights}

Staff resources designated for the protection of intellectual property rights are closely correlated with the level of priority treatment received by intellectual property rights in individual Member States, the number of applications for action (AFAs) submitted at a national level, the organisation of customs department responsible for the handling of AFAs and the role it performs. In most Member States customs departments designated to process applications for action operate at the central level.

The role of these departments may be so defined that tasks concerning intellectual property rights are highly centralised within a given Member State (which also concerns the level involved in the procedures for the notification of right holders and the holder of goods/the declarant of detentions initiated by local customs offices). As regards the central level in Poland, there is the Intellectual Property Right Protection Unit at the Customs Department (Zespół ds. ochrony praw własności intelektualnej w Departamencie Cef) of the Ministry of Finance. Like in certain Member States, intellectual property right protection coordinators have been appointed at the local level (in main offices dealing with matters concerning intellectual property rights, namely in Tax Administration Chambers (Izba Administracji Skarbowej).

Compared to 2017, in 2018 a decline in the detentions of IPR-infringing goods was seen in the majority of EU countries (and such a downward trend was also noticed in Poland), however, the number of consignments detected by customs officers from Portugal increased by 12 times. Similar tendencies can be observed, comparing statistics on the number of detained fakes. In Poland and many other countries, a drop in detained counterfeit goods was reported, whereas in Croatia - this number increased over 30 times, and in Hungary - over 20 times. It must be emphasised that the EU offers freedom to decide on a place of customs clearance, irrespective of the final destination of goods. Consequently, dishonest economic operators, deterred by effective actions taken by customs of one country, may attempt to transport illicit goods across the borders of another Member State. Compared to such countries as Germany, Belgium, France, Spain or the United Kingdom, in Poland relatively few detentions and IPR-infringing articles are reported (Fig. 3; Fig. 4). In the years 2013-2017, the share of goods detained by Polish customs authorities in all detentions in the EU was $2.1 \%$, and as regards the estimated value of detained items $-1.4 \%$ (EUIPO, 2019b).

As regards the number of detentions and the number of IPR-infringing goods detained by Polish customs authorities (based on the latest available data), a downward trend can be observed, as in the case of the EU (Fig. 3; Fig. 4). While the number of detentions of counterfeit goods, for example in 2011, 2012 totalled nearly 4,000, 2016 saw slightly more than 1,000 cases (cf. Fig. 3). Similarly, when it comes to the number of detained goods: in 2011, it was over 6 million goods, and in 2016, slightly more than 2 million (Fig. 4). On the 
other hand, the number of applications for action to be taken by customs authorities was on the rise, specifically Union applications (cf. Fig. 5).

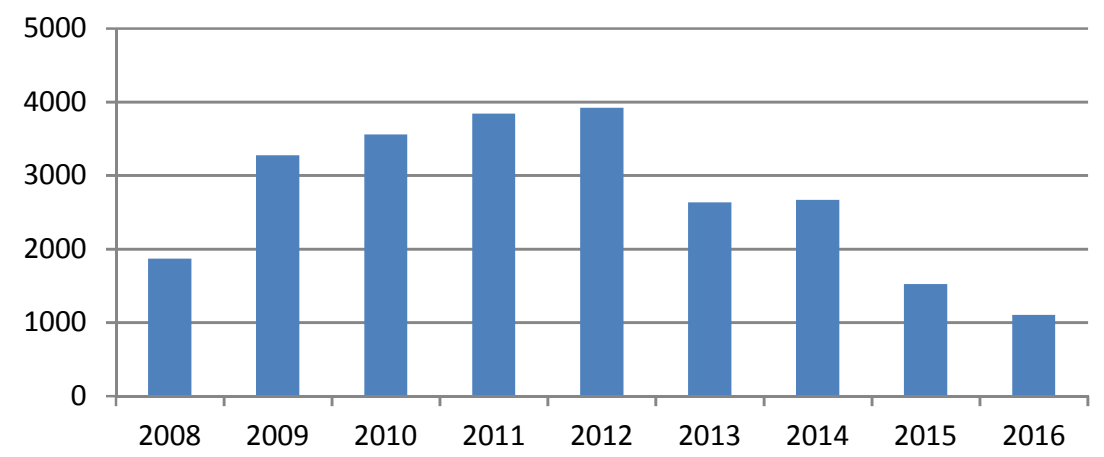

Figure 3. Number of Detentions of IPR-infringing Goods in Poland between 2008 and 2016 Source: own elaboration on the basis of Służba Celna (2014); Pogorzelski (2017).

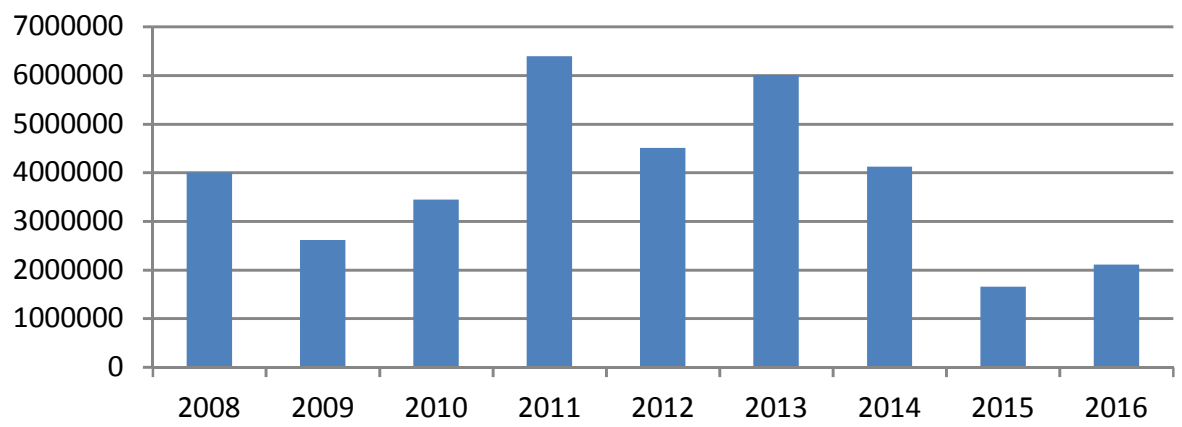

Figure 4. Number of IPR-infringing Goods Detained in Poland between 2008 and 2016 Source: the same as for Figure 3.

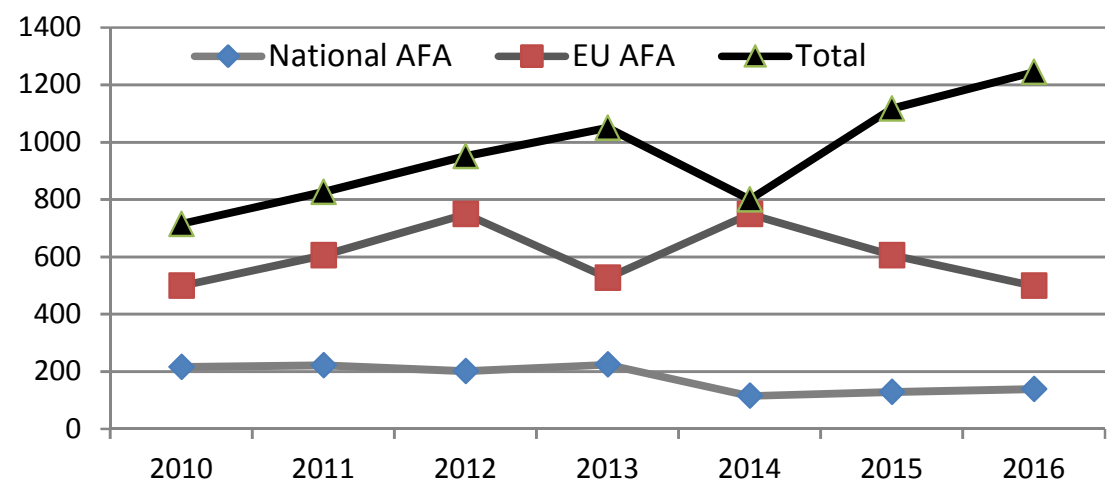

Figure 5. Number of Applications for Action to Be Taken by Customs Authorities in Poland between 2010-2016

Source: the same as for Figure 3. 
As for the share of detained goods, proportions for respective years vary slightly, nevertheless most of detained goods were cigarettes (mainly at the eastern border), pharmaceuticals, games, sports gear and toys, cosmetics, watches, jewellery and accessories, mobile phones and accessories and clothing (similarly to the entire EU). Nevertheless, sealing the eastern border, pursuing a stringent policy for tight controls at border crossing points, providing additional equipment (especially at the border with Ukraine) and suspending the local border traffic agreement with the Kaliningrad oblast bring effects.

\section{CONCLUSIONS}

The protection of intellectual property rights is a matter of paramount importance and increasing priority for governments. Its significance is reflected through the key role it plays in fostering innovation and development on the one hand, and growing concerns over the negative consequences of counterfeiting and piracy for the economy, companies and society on the other. The infringement of IPR is no longer limited to branded products such as clothes, luxurious watches, brand-name sunglasses, handbags, but it also concerns more and more popular foodstuffs, pharmaceuticals, chemicals, electronic items and household appliances. These goods, which often do not to comply with standards, may pose a serious risk to consumers' health and lives. Furthermore, it appears that counterfeit products more and more frequently enter into legal distribution systems, which means that they are available at shop shelves. Organised criminal gangs are perceived as groups that play a more and more influential role in this regard, as they gain substantial benefits from highly profitable counterfeiting and piracy operations. And finally, the greater use of the Internet as a sales platform for selling products has opened up a new market, which counterfeiters and pirates quickly took advantage of. Hence priority is assigned to fostering greater international co-operation with a view to restricting trade in counterfeit and pirated products. The growing priority is reflected through efforts undertaken by governments and business society in recent years in order to enhance the effectiveness of intellectual property policies and programmes all over the world.

The European Union has been taking actions aimed at the protection of intellectual property rights for more than three decades. An important element of combating counterfeit and pirated goods is customs control based on a risk analysis. Therefore customs authorities of Member States, including also the Polish customs, perform an influential role in the identification and detention of consignments containing IPR infringing goods at borders. Pursuant to harmonised EU regulations, customs authorities have the right to detain goods at a border either on application of the right holder who believes that goods infringe their intellectual property rights or ex officio, that is to say, on their own initiative, in the event of suspected infringement. The right holder may - throughout the period during which goods are under customs authorities' control - institute court proceedings to determine whether infringement has been committed or not. Furthermore, the EU law provides for expedited proceedings, in which case detained goods are destroyed without the need to resort to judicial proceedings to determine whether IPR has been infringed, provided, however, that an alleged perpetrator gives their express or tacit consent to such destruction.

Statistics of the European Commission indicate a continuously high number of articles suspected of infringing intellectual property rights. In 2018, over 26 million such goods were detained, with the estimated value of their genuine equivalents totalling slightly more than 
EUR 730 million. As regards detentions, the same goods have been still (for the past four years) occupying the prominent place, namely clothing and footwear. These are usually goods which can be ordered online and shipped by post or a courier company. The number of detained goods in Poland is also considerable, despite a continuous downward trend in this regard, which has been seen in recent years. However, it must be noted that detentions account only for a few per cent of all counterfeit articles in circulation. Official data on detention of goods are used in this article. This is a significant limitation of the conducted research.

Having considered the large body of evidence indicating the extent and impact of IP-related crime on the EU's economy and society, efforts to combat intellectual property right infringement must be strengthened, irrespective of actions which have been already undertaken to counteract the threat in question. Entities and institutions that serve a prominent role in combating crime associated with IPR face a number of limitations and challenges, such as the need for coordination of cross-border investigations and new technologies used by offenders to conceal their location and activities. Better coordination between EU's institutions and authorities involved in combating intellectual property right infringements and greater co-operation in the law enforcement process, as well as simplified exchange of data are necessary in order to reduce counterfeiting and piracy. Such coordination and co-operation are also required due to the fact that the EU offers freedom to decide on a place of customs clearance, irrespective of the final destination of goods. As a consequence of such freedom, dishonest economic operators, deterred by effective actions taken by customs of one country, may attempt to transport illicit goods across the borders of another Member State.

The study is an introductory one, and it faced some data limitations. Further research should include changes that are taking place in EU regulations and actions in the field of intellectual property protection. The studies should also analyze the effectiveness of customs authorities in the protection of intellectual property rights.

\section{REFERENCES}

Acquah, D. (2015). Trends on the implementation of the EU Customs Regulation: for better or for worse?, Journal of Intellectual Property Law \& Practice, 10, 775-784.

Albers-Müller, N. D. (1999). Consumer misbehaviour: Why people buy illicit goods. Journal of Customer Marketing, 16(3), 273-287.

Alfadhel, L. (2015). TRIPS and the Rise of Counterfeiting: A Comparative Examination of Trademark Protection and Border Measures in the European Union and the Gulf Cooperation Council. Journal of Trade, Law, and Development, 7(2), 1-20. http://dx.doi.org/10.1108/07363769910271504

Berman, B. (2008). Strategies to detect and reduce counterfeiting activity. Business Horizons, 51(3), 191-199.

Bloch P.H., Bush R.F., \& Campbell L. (1993). Consumer "accomplices" in product counterfeiting: a demand-side investigation. Journal of Consumer Marketing, 10(4), 27-36. DOI: 10.1108/07363769310047374

Bush, R.F., Bloch, P. H., \& Dawson, S. (1989). Remedies for product counterfeiting. Business Horizons, 32(1), 59-65. https://doi.org/10.1016/0007-6813(89)90027-X

Casola, L., Kemp, S., \& Mackenzie, A. (2009). Consumer decisions in the black market for stolen or counterfeit goods. Journal of Economic Psychology, 30(2), 162-171. https://doi.org/10.1016/j.joep.2008.06.002 
Cesareo., L., Stötinger, B. (2015). United we stand, divided we fall: How firms can engage consumers in their fight against counterfeits. Business Horizons 58(5), 527-537.

Chaudhry, P.E. (Ed.) (2017). Handbook of Research on Counterfeiting and Illicit Trade. Edward Elgar Publishing.

Chaudhry, P.E., Cordell, V., \& Zimmerman, A. (2005). Modelling anti-counterfeiting strategies in response to protecting intellectual property rights in a global environment. The Marketing Review, 5(1), 57-66.

Chaudhry, P.E., Walsh, M. G. (1996). An assessment of the impact of counterfeiting in international markets. Columbia Journal of World Business, XXXI(3), 34-48.

Chaudhry, P.E., Zimmerman, A. (2009). The economics of counterfeit trade: Governments, consumers, pirates, and intellectual property rights. Springer.

Chaudhry, P., Zimmerman, A., Peters J. R., \& Cordell, V. (2009). Preserving intellectual Property rights: Managerial insight into the escalating counterfeit market quandary. Business Horizons, 52(1), 57-66. DOI: 10.1016/j.bushor.2008.04.003

Cho, S-H., Fang, X., \& Tayur, S. (2015). Combating strategic counterfeiting in licit and illicit supply chains. Manufacturing \& Service Operations Management, 17(3), 273-289.

Commission Implementing Regulation (EU) No 1352/2013 of 4 December 2013 establishing the forms provided for in Regulation (EU) No 608/2013 of the European Parliament and of the Council concerning customs enforcement of intellectual property rights, OJ L 341, 18.12.2013, 10-31.

Commission notice on the customs enforcement of Intellectual Property Rights concerning goods brought into the customs territory of the Union without being released for free circulation including goods in transit, (2016/C 244/03), OJ C 244, 5.7.2016, 4-9.

Commission Regulation (EC) No 1891/2004 of 21 October 2004 laying down provisions for the implementation of Council Regulation (EC) No 1383/2003 concerning customs action against goods suspected of infringing certain intellectual property rights and the measures to be taken against goods found to have infringed such rights, $O J \operatorname{l} 328,30.10 .2004,16-49$.

Commission Regulation (EC) No 1172/2007 of 5 October 2007 amending Commission Regulation (EC) No 1891/2004 of 21 October 2004 laying down provisions for the implementation of Council Regulation (EC) No 1383/2003 concerning customs action against goods suspected of infringing certain intellectual property rights and the measures to be taken against goods found to have infringed such rights, OJ L 261, 6.10.2007, 12-23.

Cordell V.V., Wongtada N., \& Kieschnick R.L. (1996). Counterfeit purchase intentions: Role of lawfulness attitudes and product traits as determinants. Journal of Business Research, 35(1), 41-53. https://doi.org/10.1016/0148-2963(95)00009-7

Council Regulation (EEC) No 3842/86 of 1 December 1986, laying down measures to prohibit the release for free circulation of counterfeit goods, $O J L 357,18.12 .1986,1-4$.

Council Regulation (EC) No 3295/94 of 22 December 1994, laying down measures to prohibit the release for free circulation, export, re-export or entry for a suspensive procedure of counterfeit and pirated goods exportation, $O J L 341,30.12 .94,8-13$.

Council Regulation (EC) No 241/99 of 25 January 1999, OJ L 27 2.2.1999, 1-5.

Council Regulation (EC) No 1383/2003 of 22 July 2003 concerning customs action against goods suspected of infringing certain intellectual property rights and the measures to be taken against goods found to have infringed such rights, OJ L 196, 2.8.2003, 7-14.

Database EUIPO. Retrieved May 03, 2020, https://euipo.europa.eu/tunnel-web/secure/webdav/guest/document_library/observatory/img/new_map/PL/images/contribution_en.png 
EUIPO (2019a). Status Report on IPR Infringement. Retrieved January 03, 2020, Retrieved January 09, 2020, from www.euipo.europa.eu.

EUIPO (2019b). Report on the EU enforcement of intellectual property rights results at EU borders and in Member States 2013-2017, Retrieved January 09, 2020,from euipo.europa.eu.

EUIPO, EUROPOL (2019). Intellectual Property Crime Threat Assessment 2019. Retrieved May 04, 2020, from euipo.europa.eu.

EU publications (2019). 2019 status report on IPR infringement. Retrieved May 03, 2020, from euipo.europa.eu.

European Commission (2003). Proposal for a Council Regulation concerning customs action against goods suspected of infringing certain intellectual property rights and the measures to be taken against goods found to have infringed such rights, COM (2003)20 final, explanatory memorandum.

European Commission (2008). Report on the EU customs enforcement of intellectual property rights: Results at the EU border 2007. Publications Office of the European Union.

European Commission (2013). Report on the EU customs enforcement of intellectual property rights: Results at the EU border 2012. Publications Office of the European Union.

European Commission (2017). Report on the EU customs enforcement of intellectual property rights: Results at the EU border 2016. Publications Office of the European Union.

European Commission (2018). Report on the EU customs enforcement of intellectual property rights: Results at the EU border 2017. Publications Office of the European Union.

European Commission (2019). Report on the EU customs enforcement of intellectual property rights: Results at the EU border 2018. Publications Office of the European Union.

Gentry J.W., Putrevu S., \& Shultz C.J. (2006). The effects of counterfeiting on consumer search. Journal of Consumer Behaviour, 5(3), 245-256. https://doi.org/10.1002/cb.176

Gentry J.W., Putrevu S., Shultz C.J., \& Commuri S. (2001). How about Ralph Lauren? The separation of brand and product in counterfeit culture. In M. C. Gilly, J. Meyers-Levy (Eds.) Advances in Consumer Research (pp. 49-59). Association for Consumer Research.

Grossman G. M., Shapiro C. (1988a). Foreign counterfeiting of status goods. Quarterly Journal of Economics, 103(1), 79-100.

Grossman G.M., Shapiro C. (1988b). Counterfeit-product trade. The American Economic Review, March, 59-75.

Harvey, M. (1987). Industrial product counterfeiting: problems and proposed solutions. Journal of Business \& Industrial Marketing, 2(4), 5-13. https://doi.org/10.1108/eb006038

Heinonen, J. A., Spink, J.,\& Wilson, J. M. (2014). When crime events defy classification: The case of product counterfeiting as white collar crime. Security Journal, 30 (2), 621-639. https://doi.org/10.1057/sj.2014.18

Jain, S. C. (1996). Problems in international protection of intellectual property rights. Journal of International Marketing, 4(1), 9-32.

Jandhyala, S. (2015). International and domestic dynamics of intellectual property protection. Journal of World Business, 50(2), 284-293. DOI: 10.1016/j.jwb.2014.10.005

Khan, B. Z., Sokoloff, K. L. (2001). The early development of intellectual property institutions in the United States. Journal of Economic Perspectives, 15(3), 233-246. DOI: 10.1257/jep.15.3.233

Krajowa Administracja Skarbowa (2017). Ochrona praw własności intelektualnej. Retrieved May 03, 2020, from https://docplayer.pl/68055403-Ochrona-praw-wlasnosci-intelektualnej.

Li, S. (2004). Why is property right protection lacking in China? An institutional explanation. California Management Review, 46(3), 100-115. DOI: 10.2307/41166223 
Liang, Z., Xue, L. (2010). The evolution of China's IPR system and its impact on the patenting behaviours and strategies of multinationals in China. International Journal of Technology Management, 51(5), 469-496. DOI: 10.1504/IJTM.2010.033815

James, M., Lemon, F. (2013). Counterfeit goods in the UK: Who is buying what and why? PricewaterhouseCoopers.

Marron, D. B., Steel, D. G. (2000). Which Countries Protect Intellectual Property? The Case of Software Piracy. Economic Inquiry, 38(2), 159-174. https://doi.org/10.1111/j.14657295.2000.tb00011.x

Mercurio, B. (2012). The Protection and Enforcement of Intellectual Property in China since Accession to the WTO: Progress and Retreat. China Perspectives [online] 1. Retrieved May 11, 2020, from http://journals.openedition.org/chinaperspectives/5795. https://doi.org/10.4000/chinaperspectives. 5795

Nill A., Shultz I. (1996). The scourge of global counterfeiting. Business Horizons, 39(6), 37-42. https://doi.org/10.1016/S0007-6813(96)90035-X

OECD (2008). The economic impact of counterfeiting and piracy. Retrieved January 11, 2020 from http://www.oecd.org/sti/38707619.pdf

Phau, I., Teah, M. (2009). Devil wears (counterfeit) Prada: A study of antecedents and outcomes of attitudes towards counterfeits of luxury brands. Journal of Consumer Marketing, 26(1), 15-27. DOI: 10.1108/07363760910927019

Piquero, N. L. (2005). Causes and prevention of intellectual property crime. Trends in Organized Crime, 8(4), 40-61. DOI: 10.1007/s12117-005-1013-0

Pogorzelski, P. (2017). Ochrona praw własności intelektualnej. Retrieved May 11, 2020 from https://www.uprp.pl/sympozjum-naukowe-ochrona-znakow-towarowych-i-wzorow-przemyslowych-w-unii-europejskiej/Lead14,58,18102,7,index,pl,text/

Report on EU Customs enforcement of Intellectual Property Rights. Results at the EU border 2018 (2019). Publications Office of the European Union.

Regulation (EU) No 608/2013 of the European Parliament and of the Council of 12 June 2013 concerning customs enforcement of intellectual property rights and repealing Council Regulation (EC) No 1383/2003, OJ L 181, 29.6.2013, 15-34.

Regulation (EU) No 952/2013 of the European Parliament and of the Council of 9 October 2013 laying down the Union Customs Code. OJ L 269, 10.10.2013, 1-101.

Rinnert, S. (2015). New European Regulation 608/2013 concerning combating counterfeit goods. World Customs Journal, 9(1), 37-42.

Służba Celna (2014). Ochrona praw własności intelektualnej. Służba Celna.

Speier, C., Whipple, J., Closs, D., \& Voss, M. (2011). Global supply chain design considerations: Mitigating product safety and security risks. Journal of Operations Management, 29(7), 721-736. https://doi.org/10.1016/j.jom.2011.06.003

Staake, T., Thiesse F., \& Fleisch E., (2012). Business strategies in the counterfeit market. Journal of Business Research 65, 658-665.

Turkyilmaz C. A., Uslu A., (2014). The role of individual characteristics on consumers' counterfeit purchasing intentions: research in fashion industry. Journal of Management, Marketing and Logistics 1(3), 259-275. DOI: 10.1016/j.jbusres.2011.03.008

Vida, I. (2007). Determinants of consumer willingness to purchase non-deceptive counterfeit products. Managing Global Transitions 5(3), 25-270.

Vrins O., (2018). Regulation (EU) No 608/2013 Concerning Customs Enforcement of Intellectual Property Rights. Wolters Kluwer Law International. https://doi.org/10.1093/jiplp/jpz166 
Wee, C.-H., Tan, S.-J., \& Cheok, K.-H. (1995). Non-price determinants of intention to purchase counterfeit goods: An exploratory study. International Marketing Review, 12(6), 19-46.

Wilson, J. M., Kinghorn, R. (2015). The global risk of product counterfeiting: Facilitators of the criminal opportunity. Center for Anti-Counterfeiting and Product Protection Backgrounder Series. Michigan State University. Retrieved May 11, 2020 from http://a-capp.msu.edu/sites/default/files/PC_Opportunity_Backgrounder_02.18.15FINAL.pdf

Widdowson, D.(2007). The Changing Role of Customs: Evolution or Revolution? World Customs Journal 1(1), 31-37.

Yang, D., Fryxell G.E., \& Sie, A.K. (2008). Anty-piracy effectiveness and managerial confidence: Insights from multinationals in China. Journal of World Business, 43(3), 321-339.

Zhang J., Zhang R. Q., (2015). Supply chain structure in a market with deceptive counterfeits. European Journal of Operational Research, 240(1), 84-97.

\section{Author}

\section{Małgorzata Czermińska}

She obtained a doctoral degree (PhD) and a habilitation degree ( $\mathrm{dr}$ hab.) at Cracow University of Economics. Her research interests include common trade policy of the European Union and its instruments, the common market of the European Union and the exercise of Its fundamental freedoms, facilitation and ensuring security in cross-border trade in goods.

Correspondence to: Prof. KAAFM, dr hab. Małgorzata Czermińska, Andrzej Frycz Modrzewski Krakow University, Faculty of Law, Administration and International Relations, ul. Gustawa Herlinga-Grudzińskiego 1, 30-705 Kraków, Poland, e-mail: mczerminska@afm.edu.pl ORCID (1) http://orcid.org/0000-0002-6935-1031

\section{Acknowledgements and Financial Disclosure}

The publication was co-financed from funds allocated to the statutory activity of the Faculty of Law, Administration and International Relations at the Andrzej Frycz Modrzewski Krakow University No WPAiSM/DS/8/2019.

\section{Copyright and License}

This article is published under the terms of the Creative Commons Attribution - NoDerivs (CC BY-ND 4.0) License

http://creativecommons.org/licenses/by-nd/4.0/

\section{Published by the Centre for Strategic and International Entrepreneurship - Krakow, Poland}

